\title{
FORAGE YIELD AND BOTANICAL COMPOSITION OF MIXTURES OF SOME PERENNIAL WARM SEASON GRASSES WITH ALFALFA (Medicago sativa L.) UNDER MEDITERRANEAN CONDITIONS
}

\author{
Selahattin CINAR ${ }^{*}$, Rustu HATIPOGLU ${ }^{2}$ \\ ${ }^{1}$ Department of Field Crops, Faculty of Agriculture, Gaziosmanpasa University, Tokat, TURKEY \\ ${ }^{2}$ Department of Field Crops, Faculty of Agriculture, Cukurova University, Adana, TURKEY \\ *Corresponding author: scinar01@ hotmail.com
}

Received: 22.10 .2013

\begin{abstract}
This research was conducted to determine forage yield and botanical composition of duo (alfalfa + one grass) and trio ( alfalfa + two grasses) mixtures of some warm season perennial grass species such as dallis grass (Paspalum dilatatum Poir.), Rhodes grass (Chloris gayana L.) and Bermuda grass (Cynodon dactylon (L.) Pers.) with alfalfa as well as their pure sowings under irrigated conditions of Mediterranean during the years of 2009-2011. In the study, green herbage yield, dry matter yield, botanical composition and land equivalent ratio (LER) were determined. The experimental design was completely randomized block design with three replications. According to the results, it was determined that the ratios of warm season grasses in the botanical composition of the mixtures declined with the establishment age while rate of alfalfa in the botanical composition of the mixtures increased. The mixtures gave higher dry matter yield than pure sowings of the species. The highest green herbage yield $\left(68.44 \mathrm{t} \mathrm{ha}^{-1}\right)$ was obtained from the mixture of alfalfa + Rhodes grass. The highest dry matter yield $\left(15.40 \mathrm{t} \mathrm{ha}^{-1}\right)$ was obtained from the mixture of alfalfa + Bermuda grass + Rhodes grass. The highest alfalfa proportion $\mathbf{( 5 0 . 0 \% )}$ was obtained from the mixture of alfalfa + Bermuda grass. The highest LER (1.63) was obtained from mixture of alfalfa + dallis grass.
\end{abstract}

Key words: Alfalfa, mixture, warm season perennial grasses, yield

\section{INTRODUCTION}

Grass-legume mixtures are preferred over pure-grass forage stands throughout the world because they often increase the total yields of herbage and protein and offer balanced nutrition (Albayrak and Ekiz, 2005). Mixtures offer several potential advantages over pure grasses or pure legumes. Some other advantages of mixtures include the control of erosion, weed control and prolonged stand longevity (Casler, 1988). Alfalfa is one of the most commonly used legumes for both hay and pasture in Turkey because of its high yield, high nutritional quality, ability to fix nitrogen and vigorous fall regrowth (Acikgoz, 2001).

Grass-legume mixtures tend to provide a superior nutrient balance and produce higher forage yields. However, grass-legume mixtures are more difficult to manage than monoculture pastures because of competition among the mixture components for light, water, and nutrients (Charles and Lehmann, 1989; Serin et al., 1998; Berdahl et al., 2001; Albayrak and Ekiz, 2005). The benefit of including legumes in mixture with grasses has long been recognized. Introducing legumes in pastures and hay fields improves forage quality and lowers the cost of production (Brown and Munsell, 1943).
The advantages of cool season legumes in cool season pastures and hay lands have been well documented, but there is little information on mixing legumes with warm season grasses. Some researcher reported that growing warm-season grasses with legumes resulted in higher dry matter yields than pure sowings (Aganoglu 1985; Blanchet et al., 1995; Larbi et al., 1995; Gettle et al., 1996; Tessema and Baars 2006 ).

Mediterranean region of the Turkey experiences long periods of drought, especially in mid-summer. High temperatures and low precipitation are detrimental to production of cool season forages. Lack of productivity of cool season pastures during the summer months often results in overgrazing. Perennial warm season grasses produce their yields in midsummer, which could provide forage production during that period (Jung et al., 1978).

Methods to effectively establish and manage dallis grass, Rhodes grass and Bermuda grass for yield have been characterized for Mediterranean conditions. Using the potential of these species to provide a dependable pasture forage supply during summer months warrants investigation of options to enhance their quality. 
Rhodes grass is one of the main sub-tropical grasses and is widely grown in Africa, Australia, Japan and South America as well as in the Middle East under irrigation for both forage and soil conservation purposes. Rhodes grass is a morphologically variable out-crossing species, which is native to east, central and southern Africa where it occurs in open grasslands.

Dallis grass is a summer-active perennial grass native to the humid sub-tropics of southern Brazil, Argentina and Uruguay. It is now widespread in many areas of the world, and is capable of very high production under suitable conditions.

Bermuda grass is native to southern Africa and southeast Asia. It has been widely used in tropical and warm temperate regions as a pasture grass and is one of the major turf grasses in the world. Bermuda grass is widely sown in the south-eastern United States, where its hybrid cultivars with improved productivity and forage quality have been developed (Skerman and Riveros, 1990).

This research was conducted to determine forage yield and botanical composition of duo (one grass + alfalfa) and trio (two grass + alfalfa) mixtures of some perennial warm season grass species such as dallis grass (Paspalum dilatatum Poir.), Rhodes grass (Chloris gayana L.) and Bermuda grass (Cynodon dactylon (L.) Pers.) with alfalfa (Medicago sativa L.) as well as their pure sowings under irrigated conditions of Mediterranean

\section{MATERIALS AND METHODS}

\section{Plot establishment}

The research was carried out during 2009-2011 growing seasons in Adana province $\left(36^{\circ} 51^{\prime} \mathrm{N}, 35^{\circ} 20^{\prime} \mathrm{E}\right.$, elevation $12 \mathrm{~m}$ ), located in the Mediterranean region of Turkey. The experimental area has typically natural Mediterranean climate with hot and dry summer and heavy precipitation during winter. According to the average of long years, the coolest month is January with a monthly mean temperature of $9.9^{\circ} \mathrm{C}$ and the hottest month is August with $28.8^{\circ} \mathrm{C}$. The total precipitation was lower in $2011(462.3 \mathrm{~mm})$ and $2010(500.6 \mathrm{~mm})$, and higher in 2009 (671.6 mm) when compared with the long-term precipitation mean $(647.1 \mathrm{~mm})$. The means of the temperature and relative humidity during the experimental period were close to the long-term means (Anonymous, 2012). The research area has a flat land; its soil texture is classified as silty clay with slightly alkaline, which contained medium organic matter, poor phosphorus $(\mathrm{P})$, zinc (Zn) and calcium (Ca) contents (Anonymous, 2007).

Dallis grass (Paspalum dilatatum Poir.), Rhodes grass (Chloris gayana L.), Bermuda grass (Cynodon dactylon (L.) Pers.) and alfalfa (Medicago sativa L.) as well as their duo (one grass + alfalfa) and trio (two grass + alfalfa) mixtures were used as experimental material.

The experiment was established according to the randomized complete block design with three replications. There were 10 treatment plots in each block. Each plot consisted of 6 rows each $5 \mathrm{~m}$ in length. The row spacing was $25 \mathrm{~cm}$. The seeding rates for dallis grass, Rhodes grass, Bermuda grass and alfalfa in pure sowing were 11 $\mathrm{kg} \mathrm{ha}^{-1}, 4 \mathrm{~kg} \mathrm{ha}^{-1}, 10 \mathrm{~kg} \mathrm{ha}^{-1}$, and $10 \mathrm{~kg} \mathrm{ha}^{-1}$, respectively. Seed mixtures consisted of $30 \%$ alfalfa and $70 \%$ grasses. Seed ratio of each grass species in trio mixtures was $35 \%$. The seeds of alfalfa and grass species were sown in the same rows. Sowing was done by hand on April $28^{\text {th }} 2009$. Plots were fertilized with $100 \mathrm{~kg} \mathrm{ha}^{-1} \mathrm{~N}$ and $100 \mathrm{~kg} \mathrm{ha}^{-1} \mathrm{P}$ at sowing (Avci, 2000). The plots were irrigated once after each harvest.

\section{Methods}

The harvest time was based on the $10 \%$ flowering stage of alfalfa (Serin et al., 1998). The plots were harvested at $5 \mathrm{~cm}$ cutting height. The plots were harvested 4, 6 and 5 times during the growing season of 2009, 2010 and 2011, respectively. The botanical composition and yield were determined from the 3 randomly located quadrats each having $0.5 \mathrm{~m}^{2}$ area in each plot. Green herbage from each quadrat was hand-separated to the mixture components. All samples were dried at $70{ }^{\circ} \mathrm{C}$ for $48 \mathrm{~h}$ and weighed. Dry matter content was determined from ground samples dried at $105^{\circ} \mathrm{C}$ for $24 \mathrm{~h}$.

The land equivalent ratio (LER) was defined as the relative area of monocrop plant required for the same yield obtained from its mixture. The LER was calculated using the formula given below (Ta and Faris, 1987):

$$
\begin{aligned}
& \text { yield of alfalfa in mixture } \\
& \text { LER :----------------------- }
\end{aligned}
$$

When LER is greater than 1, the mixed growing favors the growth and yield of the mixture species. In contrast when LER is lower than 1, the mixed growing negatively affects the growth and yield of plants grown in mixture (Caballero et al., 1995; Dhima et al., 2007)

$$
\begin{gathered}
\text { yield of grass in mixture } \\
\text { yield of grass alone } \\
\text { Experimental design and statistical analyses }
\end{gathered}
$$

The experimental design was completely randomized design with 3 replications. Data were analyzed by using MSTATC (V.1.2, Michigan State University, USA). The differences between means were separated by Duncan multiple range test $(\mathrm{P} \leq 0.05)$, however means of year were compared according to least significant difference (LSD) test $(\mathrm{P} \leq 0.05)$ ( Steel and Torrie, 1960). 


\section{RESULTS AND DISCUSSION}

\section{Green herbage yield}

The results of the variance analysis showed that effects of treatments, years as well as year $\mathrm{x}$ treatment interactions on the green herbage yield were statistically significant (Table 1). Averaged green herbage yields in the first and third years were significantly higher than that in the second year. Lower averaged green herbage yield in the second year was due to lower yields of the grasses in that year. The lower yields of the grasses in the second year may be due to harmful effect of the cutting height at $5 \mathrm{~cm}$ on the warm season grasses in the first year (Jones, 1985).

Table 1. Averaged green herbage yields $\left(\mathrm{t} \mathrm{ha}^{-1}\right)$ of pure sowings and mixtures of some perennial warm season grasses with alfalfa

\begin{tabular}{lllll}
\hline Mixture or Pure Sowing & $\mathbf{2 0 0 9}$ & Years & Average \\
\hline Alfalfa (A) & $30.72 \mathrm{~d} *$ & $53.57 \mathrm{ab}$ & $49.00 \mathrm{bc}$ & $44.43 \mathrm{~cd}$ \\
Dallis grass (DG) & $54.04 \mathrm{bc}$ & $22.83 \mathrm{de}$ & $26.03 \mathrm{~d}$ & $34.30 \mathrm{de}$ \\
Bermuda grass (BG) & $37.19 \mathrm{~cd}$ & $19.61 \mathrm{e}$ & $23.61 \mathrm{~d}$ & $26.80 \mathrm{e}$ \\
Rhodes grass (RG) & $76.85 \mathrm{a}$ & $35.61 \mathrm{~cd}$ & $47.74 \mathrm{bc}$ & $53.40 \mathrm{bc}$ \\
A+DG & $46.03 \mathrm{~b}-\mathrm{d}$ & $62.07 \mathrm{ab}$ & $72.00 \mathrm{a}$ & $60.03 \mathrm{ab}$ \\
A+BG & $36.46 \mathrm{~cd}$ & $52.42 \mathrm{~b}$ & $62.64 \mathrm{ab}$ & $50.51 \mathrm{bc}$ \\
A+RG & $82.29 \mathrm{a}$ & $61.91 \mathrm{ab}$ & $61.13 \mathrm{ab}$ & $68.44 \mathrm{a}$ \\
A+DG+RG & $65.13 \mathrm{ab}$ & $55.16 \mathrm{ab}$ & $67.56 \mathrm{a}$ & $62.62 \mathrm{ab}$ \\
A+BG+DG & $34.20 \mathrm{~cd}$ & $47.31 \mathrm{bc}$ & $44.43 \mathrm{c}$ & $41.98 \mathrm{~cd}$ \\
A+BG+RG & $62.72 \mathrm{ab}$ & $67.79 \mathrm{a}$ & $72.10 \mathrm{a}$ & $67.54 \mathrm{a}$ \\
Average & $52.56 \mathrm{a}+$ & $47.83 \mathrm{~b}$ & $52.63 \mathrm{a}$ & 51.00 \\
\hline * Means with the same letter in a column are not statistically significant different from each other according to the Duncan test at P $\leq 0.05$ \\
+) Means with the same letters in the row not statistically significant different from each other according to the LSD test at P $\leq 0.05$
\end{tabular}

Pure sowings and mixtures in the first year showed statistically significant differences in green herbage yield. Mixture of alfalfa + Rhodes grass gave significantly higher green herbage yield $\left(82.29 \mathrm{t} \mathrm{ha}^{-1}\right)$ than all of the treatments with the exceptions of pure Rhodes grass (76.85 $\left.\mathrm{t} \mathrm{ha}^{-1}\right)$ and mixtures of alfalfa+dallis grass + Rhodes grass $\left(65.13 \mathrm{t} \mathrm{ha}^{-1}\right)$ and alfalfa+Bermuda grass + Rhodes grass $\left(62.72 \mathrm{t} \mathrm{ha}^{-1}\right)$.

In the second year, the highest green herbage yield was obtained from mixture alfalfa + Bermuda grass + Rhodes grass $\left(67.79 \mathrm{t} \mathrm{ha}^{-1}\right)$. Pure growing of alfalfa $\left(53.57 \mathrm{t} \mathrm{ha}^{-1}\right)$ and the mixtures of alfalfa + dallis grass $\left(62.07 \mathrm{t} \mathrm{ha}^{-1}\right)$, alfalfa + Rhodes grass $\left(61.91 \mathrm{t} \mathrm{ha}^{-1}\right)$ and alfalfa + dallis grass + Rhodes grass $\left(55.16 \mathrm{t} \mathrm{ha}^{-1}\right)$ gave the green herbage yields being not statistically significant different from the from mixture alfalfa + Bermuda grass + Rhodes grass.

In the third year, the highest green herbage yield was obtained from alfalfa + Bermuda grass + Rhodes grass $\left(72.10 \mathrm{t} \mathrm{ha}^{-1}\right)$ as in the second year. The mixtures of alfalfa + dallis grass $\left(72.00 \mathrm{t} \mathrm{ha}^{-1}\right)$, alfalfa + dallis grass + Rhodes grass (67.56 $\left.\mathrm{t} \mathrm{ha}^{-1}\right)$, alfalfa + Bermuda grass $\left(62.64 \mathrm{t} \mathrm{ha}^{-1}\right)$, and alfalfa + Rhodes grass $\left(61.13 \mathrm{t} \mathrm{ha}^{-1}\right)$ gave the green herbage yield being not significantly different from the mixture of alfalfa + Bermuda grass + Rhodes grass.

According to the values averaged over three years, the mixtures of alfalfa + Rhodes grass and alfalfa + Bermuda grass + Rhodes grass gave significantly higher green herbage yield than the pure growing and other mixtures with the exceptions of the mixtures of alfalfa + dallis grass + Rhodes grass and alfalfa + dallis grass.
As a result of the study some of the mixtures studied were superior to the single grass or legume stands. The similar results were also reported by Albayrak and Ekiz (2005), and Gökkus et al. (1999). The higher performance of the mixtures may be due to utilization of symbiotically fixed nitrogen by the grasses in the mixture and more enhanced interception of light (Hay and Walker, 1995) as well as due to synergetic and some other effects. Sleugh et al. (2000) stated that alfalfa and mixtures of alfalfa produced greater yields because the deep root system of alfalfa plants was able to tap deeper soil water.

\section{Dry matter yield}

The results of the variance analysis showed that effects of treatments, years, and year $\mathrm{x}$ treatment interactions on the dry matter yield were statistically significant (Table 2). The averaged dry matter yield in the first year was statistically significant lower than those in the second and third years. However, averaged green herbage yield in the second year was significantly lower than those in the first and third years. The reason of the contradiction between the averaged green herbage yields and dry matter yields may be differences in dry matter contents of the green herbage in the different years. In the first year, grasses in the mixture were dominant but alfalfa was the dominant species in the second and third years. Because of the higher leaf/stem ratio of the grasses as compared with much of the legumes, dry matter content of the grasses is lower than the legumes (Smetham, 1990). Therefore, dry matter yields of the mixtures in the first year were lower than those in the other years while green herbage yields were higher in the first year than those in the other years. 
Table 2. Averaged dry matter yields $\left(\mathrm{t} \mathrm{ha}^{-1}\right)$ of pure sowings and mixtures of some perennial warm season grasses with alfalfa

\begin{tabular}{lllll}
\hline Mixture or Pure Sowing & $\mathbf{2 0 0 9}$ & $\begin{array}{l}\text { Years } \\
\mathbf{2 0 1 0}\end{array}$ & $\mathbf{2 0 1 1}$ & Average \\
\hline Alfalfa (A) & $6.93 \mathrm{c}^{*}$ & $12.95 \mathrm{bc}$ & $11.28 \mathrm{bc}$ & $10.39 \mathrm{~cd}$ \\
Dallis grass (DG) & $10.97 \mathrm{a}-\mathrm{c}$ & $6.98 \mathrm{e}$ & $6.11 \mathrm{~d}$ & $8.02 \mathrm{de}$ \\
Bermuda grass (BG) & $9.46 \mathrm{bc}$ & $7.27 \mathrm{e}$ & $5.51 \mathrm{~d}$ & $7.42 \mathrm{e}$ \\
Rhodes grass & $14.73 \mathrm{a}$ & $9.64 \mathrm{de}$ & $11.27 \mathrm{bc}$ & $11.88 \mathrm{bc}$ \\
A+DG & $9.84 \mathrm{bc}$ & $16.19 \mathrm{ab}$ & $16.68 \mathrm{a}$ & $14.23 \mathrm{ab}$ \\
A+BG & $9.77 \mathrm{bc}$ & $13.51 \mathrm{a}-\mathrm{c}$ & $14.49 \mathrm{ab}$ & $12.59 \mathrm{a}-\mathrm{c}$ \\
A+RG & $14.43 \mathrm{a}$ & $14.91 \mathrm{a}-\mathrm{c}$ & $14.28 \mathrm{ab}$ & $14.54 \mathrm{ab}$ \\
A+DG+RG & $12.97 \mathrm{ab}$ & $14.35 \mathrm{a}-\mathrm{c}$ & $15.78 \mathrm{a}$ & $14.37 \mathrm{ab}$ \\
A+BG+DG & $8.17 \mathrm{c}$ & $12.35 \mathrm{~cd}$ & $10.30 \mathrm{c}$ & $10.27 \mathrm{~cd}$ \\
A+BG+RG & $12.66 \mathrm{ab}$ & $16.71 \mathrm{a}$ & $16.81 \mathrm{a}$ & $15.40 \mathrm{a}$ \\
Average & $10.99 \mathrm{~b}+$ & $12.49 \mathrm{a}$ & $12.25 \mathrm{a}$ & 11.91 \\
\hline * Means with the & same letter in a column are not statistically significant different from each other according to the Duncan test at P<0.05
\end{tabular}

* Means with the same letter in a column are not statistically significant different from each other according to the Duncan test at $\mathrm{P} \leq 0.05$

+ ) Means with the same letters in the row not statistically significant different from each other according to the LSD test at P $\leq 0.05$

In the first year, pure growing of Rhodes grass and its mixture with alfalfa gave statistically significant higher dry matter yield than all of the other pure growing with the exception of dallis grass and all of the other mixtures with the exceptions of alfalfa + dallis grass + Rhodes grass and alfalfa + Bermuda grass + Rhodes grass .

In the second year, mixture of alfalfa + Bermuda grass + Rhodes grass gave significantly higher dry matter yield than all of the pure growing and the mixture of alfalfa + Bermuda grass + dallis grass.

In the third year, the highest dry matter yield was obtained from the mixture of alfalfa + Bermuda grass + Rhodes grass with a dry matter yield being not significantly different from the dry matter yields of all of the other mixtures with the exception of alfalfa + Bermuda grass + dallis grass.

Based on the averaged dry matter yields over three years, the mixture of alfalfa + Bermuda grass + Rhodes grass was the best performed mixture while its averaged dry matter yield was not significantly different from those of the other mixtures with the exception of alfalfa + Bermuda grass + dallis grass.

Several researches reported that mixtures had higher dry matter yields than monoculture for grasses and legumes (Gokkus et al., 1999; Sleugh et al., 2000; Albayrak et al., 2011), consistent with our results.

\section{Botanical composition}

Contribution of alfalfa to the dry matter yields of the mixtures significantly changed depending on the years (Table 3). In the first year of the experiment, averaged ratio of the alfalfa ( $12.7 \%$ ) was significantly lower than those in the other two years $(55.0 \%$ and $52.5 \%$ respectively). This result was an expected result because alfalfa cannot show its potential yield in the establishment year while growing of the warm season grasses in the first year is much better than the alfalfa. This result coincides with the result of the study conducted by El Hadj (2000).

The analysis of variance showed that contribution of the alfalfa to the dry matter yield of the mixtures in the first and second years of the experiment was not significantly influenced by the mixtures. In the third year, ratios of the alfalfa in the mixtures containing Rhodes grass was significantly lower than the other mixtures with the exception of alfalfa+ Bermuda grass+ dallis grass. From this result, it could be said that alfalfa can better compete with dallis grass and Bermuda grass than with Rhodes grass.

Table 3. Alfalfa proportions (\%) in dry matter yields of different alfalfa-warm season grass mixtures

\begin{tabular}{|c|c|c|c|c|}
\hline \multirow{2}{*}{ Mixture } & \multicolumn{3}{|c|}{ Years } & \multirow{2}{*}{ Average } \\
\hline & 2009 & 2010 & 2011 & \\
\hline $\mathrm{A}+\mathrm{DG}$ & 18.3 & 48.4 & $53.5 \mathrm{a}^{*}$ & $43.4 \mathrm{ab}$ \\
\hline $\mathrm{A}+\mathrm{BG}$ & 20.8 & 62.9 & $66.3 \mathrm{a}$ & $50.0 \mathrm{a}$ \\
\hline $\mathrm{A}+\mathrm{RG}$ & 6.9 & 53.3 & $42.8 \mathrm{~b}$ & $34.3 \mathrm{~b}$ \\
\hline $\mathrm{A}+\mathrm{DG}+\mathrm{RG}$ & 10.8 & 56.6 & $39.8 \mathrm{~b}$ & $35.7 \mathrm{~b}$ \\
\hline $\mathrm{A}+\mathrm{BG}+\mathrm{DG}$ & 10.7 & 52.9 & $57.4 \mathrm{ab}$ & $40.3 \mathrm{ab}$ \\
\hline $\mathrm{A}+\mathrm{BG}+\mathrm{RG}$ & 8.5 & 55.8 & $44.9 \mathrm{~b}$ & $36.4 \mathrm{~b}$ \\
\hline Average & $12.7 \mathrm{~b}+$ & $55.0 \mathrm{a}$ & $52.5 \mathrm{a}$ & 40.1 \\
\hline
\end{tabular}

* Means with the same letter in a column are not statistically significant different from each other according to the Duncan test at $\mathrm{P} \leq 0.05$

+ ) Means with the same letters in the row not statistically significant different from each other according to the LSD test at P $\leq 0.05$ 
Based on the averaged values of the 3 years, proportion of alfalfa in the dry matter yield of alfalfa+ Bermuda grass mixture was significantly higher than those in the dry matter yields of the mixtures containing Rhodes grass.

\section{Land Equivalent Ratio (LER)}

LER verifies the effectiveness of mixtures for using available resources of environment compared to pure cropping. For this purpose, LER value is being used frequently to compare effectiveness of the mixtures and pure growing (Yilmaz et al., 2005, Dhima et al., 2007, , Atis et al., 2012). In this experiment, LER values were greater than 1 in all mixtures and in all years with the exception of the trio mixture of alfalfa+Bermuda grass+ dallis grass (Table 4). This finding demonstrated that mixtures were advantageous compared to their pure stands. Some researchers emphasized on the advantages of intercropping (Albayrak and Ekiz, 2005, Albayrak et al., 2011, Atis et al., 2012).

Table 4. Land equivalent ratios in different alfalfa-warm season grass mixtures

\begin{tabular}{lllll}
\hline Mixture & \multicolumn{2}{c}{ Years } & Average \\
\hline A+DG & $\mathbf{2 0 0 9}$ & $\mathbf{2 0 1 0}$ & $\mathbf{2 0 1 1}$ & $1.63 \mathrm{a}$ \\
A+BG & $1.03 \mathrm{a}^{*}$ & $1.93 \mathrm{a}$ & $1.94 \mathrm{a}$ & $1.43 \mathrm{~b}$ \\
A+RG & $1.11 \mathrm{a}$ & $1.45 \mathrm{c}$ & $1.74 \mathrm{~b}$ & $1.21 \mathrm{~d}$ \\
A+DG+RG & $1.06 \mathrm{a}$ & $1.30 \mathrm{~d}$ & $1.27 \mathrm{f}$ & $1.33 \mathrm{c}$ \\
A+BG+DG & $1.10 \mathrm{a}$ & $1.33 \mathrm{~cd}$ & $1.54 \mathrm{~d}$ & $1.19 \mathrm{~d}$ \\
A+BG+RG & $0.83 \mathrm{~b}$ & $1.45 \mathrm{bc}$ & $1.29 \mathrm{e}$ & $1.46 \mathrm{~b}$ \\
Average & $1.17 \mathrm{a}$ & $1.57 \mathrm{~b}$ & $1.65 \mathrm{c}$ & 1.37 \\
\hline
\end{tabular}

* Means with the same letter in a column are not statistically significant different from each other according to the Duncan test at $\mathrm{P} \leq 0.05$

+) Means with the same letters in the row not statistically significant different from each other according to the LSD test at P $\leq 0.05$

LER value was significantly influenced by the years and mixtures. The interaction of year $\mathrm{x}$ mixture was also statistically significant. The averaged LER value in the first year was significantly lower than those in the second and third years. Reasons of the higher LER values in the second and third years compared to the first year could be increasing the contribution of the alfalfa to the dry matter yield of the mixtures as well as better benefiting of the grasses from the fixed nitrogen through the alfalfa in the second and third years of the experiment. Erkovan (2005) reported that nitrogen transfer from the fixed nitrogen by legumes to the grasses in the legume-grass mixtures was higher in the second and third years than in the first year.

In the first year of the experiment, the trio mixture of alfalfa+ Bermuda grass + dallis grass showed significantly lower LER value than the other mixtures. This result shows that competition among the species of this mixture in the first year was more intensive than among the species of the other mixtures. In the second and third years as well as according to the averaged values of the three years, the duo mixture of dallis grass and alfalfa gave significantly higher LER value than the other mixtures. This result shows that the mixture of alfalfa and dallis grass was the most harmonious mixture among the studied mixtures.

\section{CONCLUSIONS}

From the results of the study, it was concluded that the duo mixture of alfalfa and dallis grass or trio mixture of alfalfa, Bermuda grass and Rhodes grass could be recommended as the summer pasture mixtures for irrigated conditions in the Mediterranean region due to their high dry matter yield, their more balanced mixture and their proper alfalfa content for safe grazing.

\section{LITERATURE CITED}

Acikgoz, E. 2001. Forage Crops. Uludag University Faculty of Agriculture Publications, Bursa

Aganoglu, V., 1985. A Research on the possibility of growing Rhodes grass (Chloris gayana Kunth) and alfalfa (M. sativa L.) in mixture under Cukurova conditions. Msc thesis, Field Crops Department of Institute for Natural and Applied Sciences, Cukurova University, Adana.

Albayrak, S., H. Ekiz, H. 2005. An investigation on the establishment of artificial pasture under Ankara's ecological conditions. Turk J Agric For 29:69-74

Albayrak, S., M. Turk, O. Yuksel and M. Yilmaz. 2011. Forage yield and the quality of perennial legume-grass mixtures under rainfed conditions. Notulae Botanicae Horti Agrobotanici Cluj, 2011, 39(1):114-118.

Anonymous. 2007. Chemical Analysis Results, University of Cukurova Laboratory of Soil Science, Faculty of Agriculture, Adana, Turkey.

Anonymous.2012. Meteorological data for Adana. http://www.wunderground.com/

Atis, A., K.Kokten, R.Hatipoglu, S. Yilmaz, M. Atak, E.Can. 2012. Plant density and mixture ratio effects on the competition between common vetch and wheat. Australian Journal of Crop Science 6 (3): 498-505

Avci, M. 2000. Determining suitable mixtures of cool season perennial grasses and legumes for establishment of short term pastures in Cukurova Region. Cukurova University, Institue of Natural and Applied Sciences, Department of Field Crops, 113 p. Adana

Berdahl, D. J., J.K.Karn, and J.R.Hendrickson. 2001. Dry Matter Yields of Cool-Season Grass Monocultures and GrassAlfalfa Binary Mixtures. Agronomy Journals, 93, 463-467.

Blanchet, K.M., J.R. George, R.M. Gettle, D.R. Buxton, and K.J. Moore. 1995. Establishment and persistence of legumes interseeded into switchgrass. Agron. J. 87: 935-941

Brown, B.A., R.I. Munsell. 1943. Grasses fertilized with nitrogen compared with legumes for hay and pasture. Agronomy Journal 35: 811-816 
Caballero, A.R., E.L. Goicoechea-Oicoechea, P.J.HernaizErnaiz. 1995. Forage yields and quality of common vetch and oat sown at varying seeding ratios and seeding rates of vetch.Field Crops Research 41:135-140

Casler, M.D. 1988. Performance of orchardgrass, smooth bromrgrass and ryegrass in binary mixtures with alfalfa. Agronomy Journal 80:509-514

Charles, J.P., and J. Lehman. 1989. The İmportance Of Grass/Legume Mixtures İ Forage Production In Switzerland. Fourages. 119:311-320

Dhima, K.V., A.S. Lithourgidis, I.B.Vasilakoglou, C.A.Dordas. 2007. Competition indices of common vetch and cereal intercops in two seeding ratio. Field Crops Research 100: 249-256

El Hadj, M. 2000. Compatibility, yield, and quality of perennial warm-season grass-legume mixtures. Master of Science In Crop and Soil Environmental Sciences, Submitted to the Faculty of the Virginia Polytechnic Institute and State University. P: 86

Erkovan, H. 2005. Some of legumes and grasses perennia forage crops in pure and mixtures pure determination of yield and transfer of nitrogen fixation. PhD Thesis, Ataturk University, Institue of Natural and Applied Sciences, Department of Field Crops, Erzurum.

Gettle, R.M., J.R. George, K.M. Blanchet, D.R. Buxton, and K.J. Moore. 1996. Frost-seeding legumes into established switchgrass. Establishment, density, persistence, and sward composition. Agron. J. 88: 98-103

Gokkus, A., A. Koc, Y.Serin, B.Comakli, M.Tan, F.Kantar. 1999. Hay yield and nitrogen harvest in smooth bromegrass mixtures with alfalfa and red clover in relation to nitrohen application. Eur Journal Agron. 10: 145-151.

Hay, R.K.M., A.J. Walker. 1989. An introduction to the physiology of crop yield. Longman Scientific and Technical, p. 292

Jung, G.A., C.F.Gross. R.E. Kocher, L.A.Burdette, and W.C.Sharp. 1978. Warm season range grasses extend beef cattle forage. Penn.Agric.Exp.Stn.Sci.Agric. 64:211-219
Jones, C.A. 1985. C4 Grasses and Cereals. Growth, development and Stress Response. A Wiley-Intersience Publication, New York.

Larbi, A., Lazier, J., Ochang, J., and Addie, A., 1995. Dry Matter Production of Thirteen Tropical Legumes İn Association with Rhodes Grass (Chloris gayana cv. Callide) on an Acid Soil in Etiopia. Tropical Grasslands Volume 29 p: 88-91. www.tropicalgrasslands.asn.au/

Serin, Y., A.Gokkus, M.Tan, A.Koc and B. Comakli. 1998. Determination of appropriate mixtures artificial grass and forage crops, Tr. J. of Agriculture and Forestry, 22, 13-20

Skerman, P.J., and F.Riveros. 1990. Tropical Grasses. FAO Plant Production and Protection Series 23, Roma. 832 p.

Smetham, M.L. 1990. The Conservation of Herbage as Hay or Silage. In: Pastures, Their Ecology and Management, R.H.M Langer (ed.), pp: 337-369, Oxford University Press, Melbourne, Oxford, New York

Sleugh, B., K.J.Moore, L.R.George, C.E.Brummer. 2000. Binary legume grass mixtures improve forage yield, quality and seasonal distrubition. Agron Jornal 92: 24-29.

Steel, R.G.D. and J.H.Torrie. 1960. Principles and Procedures of Statistics With Special Reference to the Biological Sciences. McGraw-Hill Book Co., Inc., London.

Ta, T.C., M.A.Faris. 1987. Effects of alfalfa proportions and clipping frequencies on timothy-alfalfa mixtures. I. Competition and yield advantages. Agron J 79:817-820

Tessema, Z. and Baars, R.M.T., 2006. Chemical Composition Dry Matter Production and Yield Dynamics of Tropical Grasses Mixed With Perennial Forage Legumes, Tropical Grasslands Volume $40 \quad$ p: $150-156$ www.tropicalgrasslands.asn.au/

Yilmaz, S. 2005. Determining intra and inter specific competition in vetch (Vicia sativa L.) and barley (Hordeum vulgare L.) mixtures. MSc Thesis, Institute of Naturel and Applied Sciences. University of Cukurova. Adana/Turkey 